\title{
Estudio sobre tres confesiones religiosas minoritarias en la Región de Murcia
}

\author{
Germán CARRILlo GarCía y Carmen M. CeRdÁ MondÉJAR \\ Universidad de Murcia \\ gcarrillo@um.es / carmacer@yahoo.es
}

\section{RESUMEN}

Fruto de un trabajo de investigación desarrollado en la Región de Murcia sobre diversidad cultural y minorías religiosas, se pretende llevar a cabo una revisión sobre la historiografía existente en torno a los orígenes históricos de tres confesiones religiosas como son musulmanes, judíos y protestantes. Así, se apuntan algunos datos sobre el hecho religioso y la vida cotidiana.

Palabras clave: Murcia, minorías religiosas, revisión historiográfica, musulmanes, judíos, protestantes.

\section{A Study of Three Minor Religious Confessional Groups in Murcia Region (Spain)}

\begin{abstract}
This is a result of an investigation work developed in the Region of Murcia (Spain) related to cultural diversity and minority religious groups. A bibliographical revision about written history were done to gather information about historical origin of three confession groups: muslim, jewish and protestant. This study presents data about the religious event on daily life.
\end{abstract}

Keywords: Murcia, minority religious, historical papers, muslim, jewish, protestant.

SUMARIO: 1. Apuntes sobre la historia de la Murcia islámica 2. Semblanza histórica sobre la presencia judía en Murcia entre los ss. XI-XV 3. La llegada de los protestantes a Murcia.

FECHA DE RECEPCIÓN: 20 DE 10 DE 2010

Con el título de «Estudio sobre Confesiones minoritarias en la Región de Murcia» la Fundación Pluralismo y Convivencia, dependiente del Ministerio de Justicia de España, inició una línea de investigación para la publicación de un libro sobre Diver- 
sidad Cultural y Religiosa en Murcia. Fruto de nuestro trabajo en esta investigación, presentamos este artículo donde hacemos referencia a los orígenes históricos en Murcia de tres confesiones concretas como son musulmanes, judíos y protestantes.

\section{APUNTES SOBRE LA HISTORIA DE LA MURCIA ISLÁMICA}

Es bien conocida la llegada y establecimiento de los musulmanes a las tierras murcianas, ya que en el 711 el general Tarik, al mando de tropas musulmanas, penetraba por el Estrecho de Gibraltar en suelo hispano aprovechando la inestabilidad social y política imperante en los reinos visigodos. Sin embargo, su entrada no es casual ya que con la muerte del rey visigodo Witiza, se produjo un enfrentamiento entre sus hijos y don Rodrigo, duque de la Bética ${ }^{1}$, apoyado por un grupo de nobles, para conseguir el trono. Ante tal enfrentamiento, los hijos de Witiza pedirán ayuda a las tropas norteafricanas para enfrentarse a los nobles rebeldes y conseguir sus derechos al trono; con esta acción «se cambiaría por completo la Historia de Hispania ${ }^{2}$ ».

En esta primera incursión, el avance musulmán se dirigió hacia el interior peninsular, quedando por el momento relegadas las zonas periféricas. Será en el 713 con Abd al Aziz cuando se inicie la conquista del sureste, partiendo desde Granada. De este modo, Abd al Aziz firmará un pacto con el noble Teodomiro, gobernador de la zona del sureste, conocido como Pacto de Tudmir, del cual se conservan cuatro versiones diferentes en fuentes islámicas posteriores, por lo cual su interpretación genera muchas dudas y controversias ${ }^{3}$. Mediante este pacto Teodomiro entrega a los musulmanes siete de sus ciudades ${ }^{4}$ además de una parte de sus rentas; a cambio, Teodomiro podría gobernar en parte de su territorio y se mantendrían los edificios de culto católico, así como la población hispanogoda que habitaba las tierras, y de la cual no constan migraciones hacia el norte. A continuación, citamos parte del texto de la

\footnotetext{
${ }^{1}$ En Hispania, cuyo nombre griego era Iberia, se establecieron tres provincias primero y posteriormente cinco, bajo la administración del Imperio Romano: Bética en el sur, Lusitania en el actual territorio de Portugal y Extremadura, Tarraconensis en el noreste, Carthaginensis, creada en el Bajo Imperio y situada en el centro y sureste de la Península Ibérica, con capital en Cartago Nova, actual Cartagena (comprendía la actual Región de Murcia, la parte oriental de Andalucía, gran parte de la Comunidad Valenciana y Castilla-La Mancha, Comunidad de Madrid y algunos territorios del sureste de Castilla y León) y Galaecia cuyo territorio se situaba en el extremo noroccidental de la Península Ibérica habitado por pueblos indoeuropeos de lengua céltica denominados galaicos. Los árabes llamaron $\mathrm{Al}$ Andalus a toda la península conquistada, aunque finalmente su nombre se restringiría a un territorio algo mayor que la Bética, dando lugar a «Andalucía».

${ }^{2}$ M. Rodríguez Llopis, Historia de la Región de Murcia, Murcia, 1999, p.40.

${ }^{3}$ Un estudio detallado de las cuatro versiones y otras fuentes existentes sobre el Pacto se puede hallar en A. Carmona González, «La capitulación de Teodomiro», Sharq Al Andalus 9 (1992) pp. 11-17.

${ }^{4}$ Las siete ciudades mencionadas en el documento serían: Awryula (Orihula), Lurqa (Lorca), Mula (Mula), Buq.sr.h (Begastri), Iyih (i), Laqant (Alicante), Ils (Elche). Gómez Moreno ha identificado la ciudad de ElloElo-Eio-Iyi(h), con la actual Algezares. (M. Gómez Moreno, Sugerencias murcianas. En homenaje al profesor Cayetano de Mergelina, Murcia, 1961). Sobre la identificación de Algezares con la ciudad de Lyi (h), cfr. R. Pocklington, «El emplazamiento de Iyi(h)» Sharq Al-Andalus 4 (1987) pp. 175-198. La identificación de este topónimo es una de las cuestiones que más ha atraído a historiadores y arabistas sobre la antigua geografía del Reino de Murcia.
} 
Crónica de 1344, cuyo relato se corresponde al del original árabe de los Ahbâr de arRâzî, conocido desde finales del siglo XIII"

diese la mitad de la dezima parte que al año su facienda valiese, e mas quatro almudes de trigo e quatro de ordio, e miel a azeyte como lo cogiessen vna parte señalada; e jurase Abelancin que non denostaria a ellos ni a su fee, nin les quemasse sus iglesias, e que los dejasse guardar su ley. E todo se lo prometio e se lo otorgo e fizo sus juramentos de non se lo quebrantar. E quando estas cartas fueron assi fechas andaba la era de los moros en nobenta e quatro años.

E (Abelancin= 'Abdal'azîz) lidio con la gente de Orihuela e de Lorca e de Valencia e de Alicante, e quisso Dios assi que los vencio. E dieronle las villas por pleitesía, e ficieronle cartas de servidumbre en que Abelancin los defendiesse e amparasse, e non partiesse los fijos de los padres, nin los padres de los fijos sinon por su placer dellos; e que obiessen su ayer como lo auian assi en el campo como en las villas, e que cada vno de los que en ellas morasen (...).

A partir de este momento, Teodomiro y los suyos establecerían su residencia en una zona próxima a Algezares que se empezó a conocer como Tudmir (la ciudad de Teodomiro).

Tras el tratado, se iniciaron los asentamientos de árabes y beréberes en las zonas próximas a los núcleos de población hispanogodos. Estos asentamientos no fueron muy numerosos ya que en un primer momento sólo se pretendía el control militar de la región. Utilizando una terminología moderna J. Manzano Martínez en la Guía islámica de la Región de Murcia, apuntará «no se pretendió establecer en un primer momento una colonia de poblamiento, sino de explotación».

No obstante, las relaciones que la población hispanogoda mantuvo con sus nuevos vecinos omeyas no fueron muy cordiales, ya que se documentan varios movimientos rebeldes a lo largo del siglo VIII, sobre todo debidos a los nuevos cambios en la propiedad de las tierras. Además, como apunta J. Manzano ${ }^{6}$ la política adoptada por los gobernantes omeyas tampoco será favorable a la constante inmigración de árabes y beréberes llegados del norte de África, negándose a rechazar las amplias ventajas obtenidas por el derecho de conquista. Ello provocará incesantes conflictos étnicos durante todo el gobierno de la dinastía omeya.

En este contexto, en el año 756 los abbasíes promoverán un golpe de estado en Damasco, lo cual provoca que el omeya Abd al-Rahman I proclame inmediatamente el emirato independiente de Córdoba replegándose sobre sí mismo. En esta situación los rebeldes norteafricanos intentarán llegar a la Península por mar, algunos penetrarán en Tudmir donde Atanagildo (sucesor de Teodomiro) y la población hispanogoda los apoyarán. Este apoyo a los abbasíes es lo que probablemente hizo que se rompiera el Pacto de Teodomiro firmado años antes.

\footnotetext{
${ }^{5}$ A. Carmona González (1992), op. cit., pp.11-17. Se trata de parte de una de las versiones por lo cual no se han de tener en cuenta el cómputo de las cantidades literales, ya que no coincide con otras versiones del mismo Pacto.

6 J. Marín Ceballos (dir.), Guía Islámica de la Región de Murcia, Murcia, Colección Ibn Arabí, 1990. 
Ante esta situación de inestabilidad política, el omeya Abd el Rahman II, sucesor de Abd el Rahman I, enviará tropas a Tudmir para pacificar los conflictos e impondrá una nueva organización administrativa que llevaba consigo la destrucción de la ciudad de Ello, una de las siete ciudades nombradas en el Pacto de Teodomiro, y el establecimiento de una nueva capital en una zona más llana $\left(\right.$ Mursiy $\left.^{7}\right)$ que centralizaría el poder. De esta manera, se entiende la fundación de la ciudad de Murcia por el califa omeya en el año 825 .

Sin embargo, las insurrecciones no cesarán y a fines del siglo IX y durante el siglo $\mathrm{X}$ es constante la llegada de tropas cordobesas a la zona para sofocar las revueltas de muladíes (antiguos cristianos convertidos al Islam), especialmente importantes en la ciudad de Lorca. No será hasta el año 929 con Abd el Rahman III como califa hasta que un emir bereber será enviado a gobernar Tudmir imponiéndose así la estabilidad social necesaria para el desarrollo económico de la zona, a través de unas sólidas estructuras administrativas que canalizaban las rentas fiscales extraídas en el territorio hacia Córdoba.

Además, apunta M. Rodríguez Llopis ${ }^{8}$ que ya a fines del siglo X se había producido la «arabización» cultural y la conversión al Islam de la población hispana, un hecho documentado arqueológicamente como en el caso de la ciudad de Minateda donde al cementerio cristiano se superpone la necrópolis islámica sin apenas distanciamiento temporal; en San Ginés de la Jara el culto cristiano se orienta hacia cultos islámicos y además sedes como la Encarnación de Caravaca y la Basílica de Algezares son abandonados tras una breve ocupación islámica, ya que la población tiende a establecerse próxima a los nuevos asentamientos que se consolidan durante el siglo X como son: Caravaca, Calasparra, Yecla... que afianzarán el control sobre las zonas rurales y servirán como nexo de las abundantes aldeas (alquerías) con las ciudades, que se ampliarán de forma paulatina durante este siglo, y la capital de Tudmir.

En este sentido, la expansión de comunidades campesinas que colonizaron tierras antes despobladas, originó una reordenación de los espacios rurales donde surgieron multitud de superficies de uso colectivo (bosques, pastos, aguas, montes) de gran importancia para la subsistencia de las familias allí asentadas y que permitían un mejor aprovechamiento de los recursos naturales y económicos.

También se atestigua la proliferación de alianzas matrimoniales entre musulmanes e hispanos, sobre todo entre las clases altas, como medio para mantener su estatus social, un claro ejemplo será el matrimonio de la hija de Teodomiro con un noble omeya. Además, apunta M. Rodríguez Llopis ${ }^{9}$ que la arabización lingüística fue simultánea a estos procesos ya que a lo largo del siglo $\mathrm{X}$ son numerosas las referencias a sabios, que procedentes de Tudmir, viajan por todo el Oriente. El tema de la lengua es muy interesante a la hora de abordar un estudio sobre la convivencia de dos ó más

\footnotetext{
${ }^{7}$ Sobre la existencia de un importante núcleo de población hispana con orígenes en una villae tardorromana, la bibliografía es abundante aunque aún no parece clara su localización. Cfr. R. Pocklington (1987), op cit., pp. 175-198.

${ }^{8}$ M. Rodríguez Llopis, op. cit., pp. 46-47.

${ }^{9}$ Idem, p. 47.
} 
culturas ya que, generalmente, se implanta la lengua de la cultura dominante $\mathrm{o}$ «conquistadora» que triunfa, absorbiendo la mayor parte de veces a las lenguas autóctonas ${ }^{10}$.

No obstante y a pesar de este rápido y gran proceso de «arabización», continuarán existiendo mozárabes (nombre dado a los cristianos que viven entre musulmanes) reacios a su asimilación con los nuevos dirigentes.

Con todo lo expuesto, se puede decir que concluido el siglo X Tudmir se había convertido en una provincia (Kura) integrada en el Estado cordobés, y en la que la ciudad de Murcia aseguraba su primacía sobre el resto de las poblaciones, con una riquísima diversidad étnica y cultural.

El siglo XI se iniciará con una grave crisis del califato fundado por Abd el Rahman III, que llevará a su desaparición hacia el año 1031, terminando así con 22 años de guerra civil. Ante la caída del poder centralizador, las grandes familias árabes, beréberes y muladíes, lucharán por gobernar sus regiones, lo que conllevará la independencia de los pequeños estados que se consolidan como emiratos independientes y el surgimiento los reinos de Taifas. En el caso de Murcia, se llegó a establecer una taifa independiente en Lorca aunque acabaron por eliminarla las continuas incursiones de la taifa sevillana.

Este clima de inestabilidad política será aprovechado por el monarca castellano Alfonso VI y sus ejércitos para avanzar desde el norte bajo la bandera de la llamada «reconquista» y combatir a los musulmanes; en este sentido es significativa la ocupación castellana del castillo de Aledo.

Ante esta situación, algunas taifas pedirán ayuda a los almorávides, confederación de tribus beréberes, que conseguirán unificar el Magreb occidental y Al-Andalus bajo un mismo Imperio con capital en Marrakech. En este punto señala Rodríguez Llopis ${ }^{11}$ «una ola de ortodoxia islámica, de intolerancia religiosa y de centralismo, basada en un férreo control militar, se extendió por todo Al-Andalus». En un primer momento, este nuevo régimen tendrá el favor de los intelectuales y el apoyo popular ya que conseguirá salvar a Al-Andalus del incesante avance cristiano hacia el sur. Sin embargo, esta situación de aparente calma duró poco tiempo ya que tanto la población andalusí como las tribus almohades, en el África subsahariana, comenzaron a manifestar su malestar ante la intransigencia religiosa y cultural impuesta por los almorávides. Hecho éste que provocará las varias incursiones de Alfonso I de Aragón en tierras del sur para recoger botines y a mozárabes temerosos.

En el caso concreto de Murcia se reavivaron las tensiones entre clanes y la oposición a la autoridad central, lo cual provocó una serie de luchas internas que acabarían con la llegada de Ibn Mardannis (lugarteniente del emir de Zaragoza Ibn Hud) al gobierno de Tudmir en 1147, coincidiendo con el desembarco almohade en tierras hispanas para enfrentarse a los almorávides. Durante los 25 años que duraría el gobier-

\footnotetext{
${ }^{10}$ Este proceso de «absorción» lingüística de unas lenguas por otras se denomina glotofagia y es una constante a lo largo de toda la Historia de las Conquistas. Calvet, Lingüística y colonialismo. Breve tratado de glotofagia, Buenos Aires, 2005.

${ }^{11}$ M. Rodríguez Llopis, op. cit., p. 54.
} 
no de Ibn Mardannis la ciudad de Murcia, convertida en capital de la corte, vivió su período de máximo esplendor desde el punto de vista político y cultural.

Será en esta época cuando se construyen suntuosos palacios, como el primer y más antiguo conjunto palatino de Santa Clara (Al- Dar al-Sugra, en el arrabal de la Arrixaca), el complejo palacial de Monteagudo (Qasr Ibn Sa'd), almunias (palacio residencial de descanso rodeado de jardines y huertos) y mezquitas.

Agricultura, ganadería, pesca serán actividades que se desarrollan paralelamente en estos años. El profesor Juan Fco. Jiménez Alcázar señala este período como el momento cumbre de Murcia tanto como ciudad y área de influencia y alude en este sentido al establecimiento del hijo del sultán en la madina murciana, constituyendo el segundo núcleo de capitalidad política y militar en la Península.

Además, será también en el siglo XII cuando se lleve a cabo la gran ampliación de la red de acequias, unida a la expansión de la gran propiedad y al aumento de la producción agraria.

Paralelo a este fenómeno se desarrollará un proceso de encastillamiento (muchas de ellas con albacara, tanto para refugio ganadero como de la población en general) que supone el desarrollo de la arquitectura defensiva en la Región de Murcia ${ }^{12}$, unido también a un desarrollo económico ya apuntado, y expresado en la llegada de numerosa población a las madinas, sobre todo almohades, y es que «el establecimiento de un estado fuerte y con garantías de seguridad hizo del reino mardanishí, un foco de inmigración intenso ${ }^{13} \gg$.

Además, la situación de calma impuesta tras la caída del poder almorávide fue aprovechada por Ibn Mardannis para iniciar su política de expansión territorial hacia toda la zona del sur andalusí. Como primer paso, se aseguró el favor y neutralidad de los reinos cristianos del norte a cambio del pago de tributos (parias) e inició su expansión hacia tierras sureñas apoyado por su suegro Ibn Hamusk. Sin embargo, su deseo de conquistar toda Andalucía, le harán descuidar la frontera norte desde donde Ramón Berenguer IV, conde de Barcelona, penetrará hasta llegar a la ciudad de Lorca en 1156.

En este sentido, tras una crisis sucesoria el nuevo califa almohade Yusuf I emprenderá su marcha desde Córdoba hasta Murcia para detener el avance mardannisí consiguiendo por fin la rendición del reino y asegurándose la solidaridad de los descendientes de Ibn Mardannis, mediante el matrimonio con una de sus hijas.

Sin embargo, con la victoria cristiana de Alfonso VIII de Castilla en las Navas de Tolosa en 1212 sobre los almohades, los andalusíes se percatan de la incapacidad almohade para defenderlos y se originan movimientos de contestación política por todo Al-Andalus.

\footnotetext{
12 En estas fechas se construyen el Castillo de Monteagudo, La Asomada, El Portazgo y otra construcción próxima (inacabados), situados en zonas geoestratégicas y que forman un cinturón defensivo que rodea a la ciudad de Murcia. En este sentido, se ha de tener en cuenta que los gastos de estas construcciones fueron sufragados mediante impuestos y tributos exigidos a los individuos y núcleos familiares, lo cual conllevaría una fuerte oposición popular a esta política fiscal.

13 J.F. Jiménez Alcázar, «La crisis del Reino Musulmán de Murcia en el siglo XIII», HID 32 (2005) p. 196.
} 
De este modo, ya en el siglo XIII asistimos a un período de crisis en el Reino musulmán murciano. No obstante, y como bien señala Jiménez Alcázar ${ }^{14}$, las raíces de este cambio profundo deben buscarse en los siglos precedentes y no analizar sólo sus consecuencias: «esa visión unilateral ha podido perjudicar las capacidades interpretativas del proceso, tanto a historiadores documentalistas como a arqueólogos: ni el período islámico fue el Paraíso Terrenal, ni la llegada de cristianos el Juicio Final, a pesar de los visibles indicios de desarrollo global del primero, y los procesos de despoblación del segundo, todo es matizable». Sin embargo, no se trata en este caso de redimir a inocentes y juzgar a culpables, simplemente, pretendemos esbozar en unas líneas un leve reflejo de la situación vivida por la población murciana en estos años de continuos enfrentamientos y peligros en las fronteras e inestabilidad política en el interior.

Así, es en este clima donde se enmarca la aventura de Ibn Hud, personaje de orígenes inciertos que las crónicas hacen descendiente de la dinastía hudita de Zaragoza $^{15}$. Desde la zona norte de Tudmir y con un ejército numeroso bajo su control, Ibn Hud dominará las tierras de Cieza y Ricote desde donde en 1228 iniciará una clara insurrección contra la capital murciana, proclamando la necesidad de acabar con el poder almohade, de unificar Al-Andalus y de restaurar la fe islámica a partir de la sumisión de los abbasíes de Bagdad. Bajo estas consignas, conseguirá entrar en Murcia derrotando a los almohades y se proclamará emir. En los años sucesivos, continuará conquistando territorios hasta crear un gran Estado con capital en Murcia y que se extendía desde Valencia, a Almería, Algeciras, Gibraltar y Ceuta.

No obstante, pronto surgieron las primeras insurrecciones contra Ibn Hud desde Arjona y Niebla, que unidas al incesante avance castellano, conseguirán acabar con el emirato murciano y reducir sus territorios que quedarán limitados al sureste peninsular.

En 1238 muere Ibn Hud y para entonces, las fronteras estaban ya muy débiles: Ibn al-Ahmar avanzaba desde Almería, y por el norte Jaime I tras conquistar Valencia proseguía su marcha hacia el sur. En el interior, se produjeron luchas políticas entre los sucesores de Ibn Hud que concluirán con la proclamación de un estado independiente y la posterior división del territorio en multitud de poblaciones autónomas. Esta situación de inestabilidad interior, favoreció el avance militar castellano hacia el sureste, y así, en 1243 la conquista del territorio murciano culminaría con la firma del tratado de Alcaraz entre Muhammad al-Dawla y Fernando III, por el que el emir murciano se sometía a vasallaje del monarca castellano; no obstante, en términos reales, desde 1230, los castellanos conquistaban poblaciones que hasta años antes habían formado parte del emirato hudita (Segura de la Sierra, Orcera, campo de Montiel, villa de Alcaraz...) y donde los santiaguistas se configuraban como los más beneficiados de este avance territorial. Además, será en estos territorios donde se inicie la repobla-

\footnotetext{
14 Idem, p. 195.

${ }^{15}$ M. Rodríguez Llopis, op. cit., p. 57.
} 
ción de las tierras, a través del asentamiento de familias castellanas emigradas desde tierras situadas más al norte ${ }^{16}$.

La consolidación del dominio castellano en tierras murcianas, animará a Fernando III a conquistar las poblaciones granadinas que lindaban con tierras murcianas, apoyándose en las fuerzas santiaguistas al mando de Santiago Rodrigo Yañez.

De esta manera, finalizado el año 1242 los castellanos se habían anexionado todo el sector septentrional del emirato, por ello en abril de 1243 se decide la firma del tratado de Alcaraz ${ }^{17}$. Entre las condiciones de sumisión se fijó la entrega al monarca castellano de la mitad de todas las rentas del emirato, el permiso para mantener en cada fortaleza una guarnición militar castellana, además de nombrar un merino mayor para todo el territorio y la defensa castellana ante cualquier ataque enemigo. Además, se aseguró la continuidad del sistema económico y social islámico, garantizando a los musulmanes el respeto de su religión y de sus propiedades.

Lorca, Mula y Cartagena rechazaron el pacto en un primer momento, sin embargo tras duros asedios y devastaciones de sus territorios, una a una terminarían por someterse quedando concluida la conquista en la primavera de 1245.

No obstante, existieron muchas contradicciones en cuanto a la conquista castellana y es que, mientras que en los territorios sometidos en Alcaraz se garantizaba el respeto de las propiedades y del sistema islámico, en otras zonas conquistadas por la fuerza, no se aplicaron los preceptos del tratado y los castellanos actuaban a su antojo. Ante tal situación, el conflicto era casi obligado.

La muerte de Fernando III supuso un cambio brusco de la política castellana respecto a la situación de los musulmanes y es que su sucesor Alfonso X inició una política de concesión de señoríos en la zonas sometidas a protectorado. Esta nueva política alfonsina produjo el levantamiento general de los mudéjares (nombre dado a los musulmanes que viven entre cristianos) murcianos contra Castilla en 1264, con gran éxito en los territorios sometidos a protectorado y de amplia población mudéjar. La situación se hizo tan crítica que Alfonso X decidió pedir ayuda a Jaime I de Aragón y así en 1265 se iniciaría propiamente la conquista de Murcia.

$\mathrm{El}$ avance cristiano fue rápido, los musulmanes pactaron la entrega de la ciudad a cambio del respeto de sus costumbres y sus bienes, aceptando la partición desigual del núcleo urbano y su concentración en el arrabal de la Arrixaca (extramuros). De este modo, en febrero de 1266 Jaime I entraba triunfal en la ciudad consagrando la mezquita mayor como catedral-Iglesia de Santa María, en contra de lo pactado días antes.

A partir de este momento, se iniciaría de forma paulatina el éxodo masivo de muchos musulmanes hacia el reino de Granada. En este caso, ocurrió un suceso os-

\footnotetext{
${ }^{16}$ Este fenómeno de la repoblación se aprecia desde el punto de vista arqueológico en el estudio de los ajuares cerámicos, y es que las antiguas marmitas islámicas, serán rápidamente absorbidas por las ollas valencianas vidriadas al interior y de paredes muy finas y pasta rojiza. Además, otras magníficas producciones de cerámica típicamente islámicas, frenarán su elaboración, tal es el caso de las cerámicas esgrafiadas, a cuerda seca, estampilladas, entre otras.

${ }^{17}$ No se conocen los documentos oficiales de este proceso, pero por las crónicas y otra documentación alternativa se sabe que la entrevista se desarrolló en Alcaraz en abril de 1243.
} 
curecido por los cronistas castellanos para no empañar la brillantez de la conquista y es que, en estas primeras emigraciones de musulmanes, el rey castellano aseguró su protección hasta las fronteras, sin embargo, en las proximidades de Huercal Overa «los traicionaron a todos en el camino (...) hicieron cautivos a las mujeres y a los niños y mataron a los hombres» (Crónica islámica).

Este exilio musulmán fue simultáneo a la llegada de inmigrantes cristianos, aunque el menor número de repobladores produjo un desequilibrio demográfico que nunca fue superado. El proceso repoblador se articuló según un plan general de asentamientos, desarrollado en varias fases, que permitió repoblar las principales ciudades al compás que eran abandonadas por sus habitantes musulmanes, mediante Repartimientos programados de casas y tierras entre los recién llegados.

Estos nuevos habitantes traían también una nueva religión y, además, con ellos llegaron también grupos de clérigos para instalarse en el territorio y predicar entre la población musulmana con la intención de convertirles. Alfonso X propiciaría este proceso apoyando la instalación de estos grupos clericales y donándoles inmuebles y rentas para el ejercicio de sus tareas.

Sin embargo, la política de conversiones fracasó ya que la mayoría de musulmanes optaron por seguir profesando el Islam, bien permaneciendo en el reino como una población cada vez más minoritaria, bien exiliándose.

En palabras de Rodríguez Llopis ${ }^{18}$, este proselitismo cristiano se alimentaba de amplias dosis de intransigencia que imposibilitó una convivencia tolerante entre ambas comunidades religiosas ${ }^{19}$. No obstante, con el asentamiento de algunas órdenes monásticas (Santa Clara, Santo Domingo...) y la recuperación de algunos cultos con orígenes visigodos (San Ginés de la Jara), se formó en la capital una reducida elite cultural cristiana con intereses políticos, misioneros y culturales, que entró en contacto con la población autóctona y sobre todo con los intelectuales árabes que aún vivían en la capital. La historiografía tradicional ha presentado estos contactos como un ejemplo de convivencia entre judíos, musulmanes y cristianos, recreando un ambiente idílico de intercambios mutuos. Sin embargo, con el transcurrir de los años se haría evidente que este etéreo proceso de convivencia estaba abocado al fracaso por estar definido a partir de la desigualdad de derechos de cada una de las comunidades y sobre la superioridad de la cultura de los conquistadores. Hecho este inherente a todo tipo de conquistas, por lo cual, poco a poco judíos y mudéjares terminarían por exiliarse o someter sus prácticas religiosas al ámbito privado.

En los años sucesivos, se irán instalando en el reino de Murcia lo que Rodríguez Llopis denomina «los poderes feudales». Poco a poco nobles y aristócratas impondrían sus derechos sobre las tierras, recurriendo al ya viejo tema de la limpieza de sangre y la clase privilegiada. Además, este sistema social feudalizado obligó a implantar las estructuras eclesiásticas que a su vez favorecían a las clases dirigentes.

\footnotetext{
${ }^{18}$ M. Rodríguez Llopis, op. cit., p. 89.

${ }_{19}$ Se narran algunos hechos acaecidos entre cristianos y musulmanes en las Cantigas, relatadas por el propio monarca Alfonso X.
} 
De esta forma, fue surgiendo poco a poco la nueva sociedad murciana, donde los principales linajes, constituidos de antiguo, fueron los dueños y garantes del patrimonio, aunque no consiguieron mantenerse al margen de las tensiones y los conflictos originados entre sus propias filas.

Durante estos años y hasta la definitiva conquista de todo el territorio por parte de los Reyes Católicos, que expulsarán a los últimos reductos de musulmanes de Granada en 1492, ya casi nada se sabía de las minorías de mudéjares, al igual que muchos cristianos de clase baja, su día a día era el trabajo y el esfuerzo y sobre todo y en años de intransigencia, la negación de sus creencias y costumbres, única forma de hacerlas sobrevivir.

\section{SEMBLANZA HISTÓRICA SOBRE LA PRESENCIA JUDÍA EN MURCIA ENTRE LOS SS XI-XV}

Sobre la presencia judía en Murcia entre los siglos XI al XV, la documentación existente no es muy abundante, y en muchos casos es controvertida y ha sido interpretada en pro de un interés determinado.

De hecho, no se sabe con certeza la fecha de su llegada ya que como apuntamos, las fuentes y documentos al respecto son más bien escasos. Los datos epigráficos más antiguos que atestiguan la presencia de familias judías en Hispania, se remontan al siglo II d.C. No obstante, su distinción desde el punto de vista arqueológico es muy difícil ya que no establecen patrones diferenciadores de tipo arquitectónico ni cerámico donde utilizan las mismas tipologías de vajilla que la población con que conviven en cada momento.

En época medieval, y más concretamente en el caso de Murcia, existen muy pocas noticias sobre judíos en el siglo XI, bajo dominio musulmán. Su presencia era tolerada y en consecuencia, recibían protección a cambio del cumplimiento de ciertas obligaciones que aparecen recogidas en algunas crónicas hispano-musulmanas. Sus barrios eran semejantes al resto del trazado musulmán: calles estrechas, callejones sin salida y casas pequeñas agrupadas en torno a plazoletas. Sus actividades laborales se centraban básicamente en el comercio, fabricación de telas y artesanía. Su vida se desarrollaba en condiciones eminentemente precarias, pues su condición política dependía en todo caso de un mero cambio del gobernante de turno y las posibles simpatías que éste sintiera por esta minoría ${ }^{20}$.

Del siglo XII sólo se dan noticias, según el Repartimiento de la ciudad de Mur$\operatorname{cia}^{21}$, de un grupo escaso de casas en la zona oriental con osario, sinagoga y alcaicería, cuyo emplazamiento exacto aún no se ha concretado ${ }^{22}$. Además, es bien sabido

\footnotetext{
${ }^{20}$ C. Carrete Larrondo, Los judios de Al-Andalus y Sefarad, (siglos XI-XIII), Elad, el hombre de la leyenda, Burgos, 2007.

21 J. Torres Fontes, El repartimiento de Murcia, Murcia, 1960, p. 316.

${ }^{22}$ Frutos Baeza y Torres Fontes plantean como emplazamientos para la sinagoga la calle Sémola, calle Alta o Luisa Aledo, calle se Victorio y plaza Sardoy (J. Frutos Baeza, Bosquejo histórico de Murcia y su consejo,
} 
que los almohades decretaron a mediados del siglo XII la expulsión de moriscos y judíos de su territorio, por lo cual la aljama ${ }^{23}$ judía podría haber desaparecido por estas fechas, para establecerse después, tras el triunfo de Ibn Hud, primeramente con grupos de mercaderes y comerciantes, que irían aumentando hasta constituir importantes núcleos de población judía entre 1243-1266 24. En este sentido, los documentos cristianos conservados en el Archivo Municipal de Murcia, dan noticias de que en el sector oriental de la ciudad medieval, se asentaba el recinto de la judería murciana durante los siglos XIII al XV ${ }^{25}$. Este hecho muestra que, al igual que los mudéjares, los judíos se asentaban en recintos separados de los cristianos.

A partir de 1266, ya bajo la soberanía de Castilla, las comunidades judías murcianas estuvieron protegidas tanto por los reyes como por la nobleza a quienes dedicaron lealtad y verdadera colaboración.

Con Alfonso X se darán una serie de Ordenanzas y algún privilegio ${ }^{26}$ relacionado con sus actividades económicas, que favorecen su estancia en Murcia; además será el rey alfonsino también el que ordene la creación de la judería en una zona periférica de la ciudad, lo cual no impedirá que realicen sus trabajos y negocios en las zonas céntricas, mezclados con la población cristiana. Las profesiones que ejercieron fueron recaudadores de impuestos, mercaderes, médicos, tenderos, artesanos, herreros y tintoreros.

A fines del siglo XIII, era tal la prosperidad económica que los judíos murcianos habían alcanzado, que pronto surgieron los roces con los cristianos ${ }^{27}$, sobre todo con aquellos a los que habían prestado dinero ${ }^{28}$. Este hecho ocasionó algunas disputas ciudadanas y la queja de los judíos al propio monarca castellano, ante la pasividad del concejo de la ciudad. Se firmó entonces un acuerdo en 1294 con un una serie de cláusulas que garantizaron la conformidad de ambos grupos, aunque no terminarían con el problema que se mantendría latente entre la población hasta su definitiva expulsión en 1492.

Durante sus años de estancia en Murcia, la comunidad judía no destacó en ninguno de los aspectos de desarrollo del Reino, es decir, no participó en la repoblación de campo y huerta ni colaboró en la empresa cultural patrocinada por Alfonso X, con-

Murcia, 1934; J. Torres Fontes, Los judios murcianos en el siglo XIII, Murcia, 1962. En cuanto al barrio judío Frutos Baeza lo sitúa entre las calles de Ochando, Selgas (en parte), Sardoy Descabezados o Siervas de Jesús (en parte), Santa Quiteria (en parte), Mesegueres, Horno, Paco, Victorio, plaza Amores, Sémola, Santa Rosalía, Torreta, Madrid (no existentes en la Edad Media), Rosario, Portillo de Lomas, Cigarral y Concepción.

${ }^{23}$ Comunidad judía que cuenta con las instituciones reglamentarias y edificios comunitarios como sinagoga, escuela, cementerio... Si no cuentan con las condiciones mínimas, se llama entonces judería.

${ }^{24}$ No obstante la judería murciana no es de las más numerosas en comparación con la de Toledo o Córdoba, para los mismos años.

25 Junto a la puerta de Orihuela, actual Barrio de Santa Eulalia.

${ }^{26}$ F. Valls y Taberner, Los privilegios de Alfonso X el Sabio a la ciudad de Murcia, Barcelona, 1923.

${ }^{27}$ Ejemplos de ello aparecen en Las Cántigas de Alfonso X, que no dejan en buen lugar a los judíos de la época, así como tampoco el famoso Poema de Mío Cid.

${ }^{28}$ El mismo Alfonso X, necesitado también de los préstamos de los judíos, limitó el interés legal de los mismos, reduciendo así sus beneficios. 
trariamente a los mudéjares que se prestaron a un intercambio cultural acorde a la política del rey alfonsino ${ }^{29}$.

Además, apunta el profesor Torres Fontes ${ }^{30}$ que en la mayoría de los casos sus problemas y cuestiones quedaron por lo general reducidos a su ámbito privado, sin resonancia exterior, la mayoría de veces resueltos por su Rabbí o Judío Mayor; así sus noticias no llegaron a las actas concejiles, con excepción de los casos relacionados con cristianos y que exigían ya, según las ordenanzas, la intervención de los regidores, miembros del concejo ${ }^{31}$.

Durante el siglo XIV, la situación se mantuvo, sin embargo, hacia el 1400 y debido a la prosperidad alcanzada, la judería vio la necesidad de ampliar su extensión, lo cual provocó las quejas y protestas de sus vecinos cristianos, hecho éste que determinaría la llegada de Juan de la Hoz, visitador de los RRCC, en 1482 y su delimitación definitiva de la judería y la construcción de tres puertas para cerrar calles y controlar los accesos del barrio judío al cristiano; de ello deducimos, pues, que con anterioridad no existía una muralla propia que delimitara el recinto. De este modo, se separaban dos mundos a los que se quería diferenciar cada vez más, comienzo de unas directrices políticas bien definidas ${ }^{32}$. En este sentido, queda claro que la creación de «estado moderno» impuesta por los recién llegados monarcas tuvo mucho que ver en la orientación de su política religiosa, la cual conllevaría además la creación del Tribunal de la Inquisición ${ }^{33}$.

No obstante, el hecho de que no existiera una separación clara de la judería antes de la llegada de Juan de la Hoz también muestra la existencia de una relativa tranquilidad y convivencia con la población cristiana hasta la fecha ${ }^{34}$, ya que como afirma el profesor Torres Fontes ${ }^{35}$ «es Murcia una de las pocas ciudades donde si en determinadas y contadas ocasiones se intenta provocar el asalto de su judería, siempre sería evitada oportunamente con el beneplácito general de su población, como sucede en los casos de los reinados de Enrique II, Enrique III y su gran protector Juan II; el trato es excelente, aunque, no obstante, existen excepciones de hechos aislados». Auque esta afirmación es bien cierta, hemos de tener en cuenta que esta asegurada protección concejil de la aljama murciana se mantenía siempre y cuando se ejerciera un imputado respeto de las propias leyes y costumbres impuestas a la sociedad murcia-

\footnotetext{
${ }^{29}$ J. Torres Fontes, «La cultura murciana en el reinado de Alfonso X», Murgetana 14 (1960) pp. 57-89.

30 J. Torres Fontes, «Murcia Medieval, Testimonio documental», Murgetana 68 (1985) pp.79-130.

31 Los concejos son las instituciones creadas para el gobierno local de las nuevas comunidades, según avanza la conquista cristiana. En la mayoría de los casos sus filas fueron monopolizadas por las familias más destacadas, aunque en sus primeros años existió más movilidad, debido también a los propios movimientos mi-

${ }^{32}$ J. Torres Fontes, «La judería murciana en época de los Reyes Católicos», Murgetana 86 (1993) pp. 89-94.

33 J.Valdeón, «Los orígenes de la Inquisición en Castilla», Inquisición y Conversos, III Curso de Cultura Hispanojudía y Sefardí de la Universidad de Castilla-La Mancha, Madrid, 1994, pp. 35-45.

${ }^{34}$ La judería murciana escapó a las feroces persecuciones que se sucedieron a finales del siglo XIV y principios XV por toda Castilla, no obstante las rencillas con cristianos y sobre todo eclesiásticos, eran continuas. Con las predicaciones de San Vicente Ferrer (1411) fueron muchos los que se convirtieron por miedo a más persecuciones o por conveniencias.

35 J. Torres Fontes, (1985), art. cit., pp. 79-130.
} gratorios. 
na en general, y a las minorías de judíos y musulmanes en particular, ya que en el marco de lo que hoy damos en llamar «políticamente correcto» toda costumbre y trabajo eran buenos siempre que se mantuvieran ciertos códigos de conducta bien impuestos y con generosa interpretación por parte del concejo regidor de la ciudad. En este sentido, una proscripción muy clara y que pesó en gran medida sobre ambas minorías era la de llevar en sus vestiduras señales para diferenciarse de $\operatorname{cristianos}^{36}$, así como también la prohibición de la relación carnal de judío o moro con una cristiana aunque ésta fuera prostituta; sobre ello se conocen algunos casos en el siglo XIV y el castigo impuesto era la pena de muerte o la quema en la hoguera. Además, tampoco se admitían cristianos al servicio de judíos o la entrada de cristianas en la judería, en palabras de Torres Fontes «Religión y raza diferenciadas y diferenciadoras. Tal era la exigencia separadora de unos y otros que imponían los tiempos, aceptada, convenida y respetada, salvo raras excepciones ${ }^{37}$ ).

Sin embargo y pese a todo, la situación cambiaría notoriamente a partir de julio de 1492 con la instauración del Tribunal de la Inquisición y las continuas persecuciones a judíos, a raíz del edicto de expulsión dado por los RRCC el 31 de marzo de 1492. Tras su expulsión, se enajenaron sus propiedades, desaparecieron las pruebas externas de su barrios (puertas, arcos, muros...), las lápidas fueron reutilizadas como material constructivo, en muy pocos casos se respetaron sus cementerios, el rastro de la sangre también se intentó borrar en pro de una limpieza que enfrentaba a familias y a bandos para abrir así una nueva línea de combate en los iniciados tiempos modernos. Con el Tribunal de la Inquisición, quedaron los conversos, sometidos a una estricta censura de costumbres y a una permanente vigilancia. Durante estos siglos de oscuridad y silencio se perdió la mayor parte del legado judío. En ese ambiente de persecución y desprecio lo que sobrevivió lo hizo a fuerza de ser negado ${ }^{38}$. Igualmente ocurrió con los mudéjares reducidos a una minoría pobre, callada y trabajadora, lejos ya de los últimos tiempos de esplendor de los descendientes de Ibn Hud.

Con todo lo escrito, no obstante, es muy difícil establecer unas conclusiones claras sobre la tolerancia o no de cristianos hacia las minorías, y sobre la convivencia de estas tres culturas asentadas en el reino de Murcia durante toda la Edad Media, ya que parafraseando de nuevo al profesor Torres Fontes «(...) el hallazgo de hechos aparentemente novedosos que configuran todo un tratamiento, y no pasan de ser casos peculiares, porque no todo es siempre igual y las relaciones humanas tienen distintas expresiones según circunstancias, o de la personalidad impositiva del magnate, corregidor,

\footnotetext{
36 J. Torres Fontes, «Moros, judíos y conversos en la regencia de don Fernando de Antequera», CHE 31/32 (1960) pp. 60-97. Orden muy controvertida ya que dichas señales quedaron en desuso desde las predicaciones de San Vicente Ferrer y las ordenanzas de Juan II, se restituirán en tiempos de los RRCC por su enviado Juan de la Hoz, para ser de nuevo prontamente depuestas.

${ }^{37}$ Un muestrario variado y amplio de las actividades de su población, de las distintas clases sociales que en ella conviven y de quienes por su raza y religión discriminados y sujetos a restricciones, difieren en usos, derechos, posibilidades y formas de vida, se puede ver en una magnífica selección de documentos medievales recogida por J. Torres Fontes, «Murcia Medieval. Testimonio documental», Murgetana 52 (1978) p. 104.

38 J.R. Ayaso, «De los 'Duelos y quebrantos' a la reivindicación de la adafina», en Actas Congreso de Arqueología Judia Medieval en la Península Ibérica, Murcia, 2009, pp. 17-30.
} 
obispo o caudillo que impone su indiscutible y temida autoridad, o del lugar, ciudad o reino de que se trate ${ }^{39} \gg$. Además, podemos aventurarnos a decir que ocurría antes como ahora que la población en su mayoría convivía, se relacionaba y mostraba unos lazos a veces más fuertes que los que indica la propia palabra tolerancia. No obstante, y como en toda relación ciudadana, existían altercados menores, relacionados las más de las veces con el factor económico, que se hacían mayores cuando con las autoridades topaban ya que eran éstos organismos los que con sus numerosas sentencias, restricciones y en casos confuso respeto, diferenciaban y excluían a las minorías de musulmanes y judíos en el Reino de Murcia.

\section{LA LLEGADA DE LOS PROTESTANTES A MURCIA}

En cuanto al estudio de los protestantes en Murcia, el estado de la cuestión ha sido objeto de escasa bibliografía científica. Muchas de las publicaciones generales sobre el protestantismo provienen de las revistas propiamente evangélicas y documentos apologéticos de las diferentes iglesias reformadas. Destacamos, dentro del ámbito académico, dos autores que han contribuido al conocimiento del protestantismo desde un punto de vista histórico cuyas obras aparecen en la década del 70: Van der Grijp, 1971 y J.B. Vilar, $1979^{40}$. Es de gran valor la investigación del profesor J.B. Vilar llevada a cabo en la población murciana de Águilas, donde realiza un estudio local ligado al contexto global de la historia de las congregaciones evangélicas. Naturalmente existen obras de carácter general sobre el protestantismo anteriores que han servido para alicatar el totum revolutum de informaciones y fuentes referenciadas a esta confesión.

En cuanto a los orígenes, se ha de indicar que el protestantismo penetra tímidamente en Murcia en el siglo XVI para refugiarse prontamente en lo privado o exiliarse del Tribunal de la Santa Inquisición hasta 1869, cuando se produce la denominada II Reforma, nombrada así por primera vez por M. D. Robert en su trabajo The dawn of the second reformation in Spain- bejin the story of its rise and progress from the year 1852.

Este primer protestantismo del XVI fue permeable para las clases nobles y cultas más relacionadas con el humanismo y la lectura de la Biblia. En este sentido, destacan intelectuales como Juan de Valdés, Francisco de Enzinas, Antonio del Corro, Cipriano de Valera, Casiodoro de Reina, autores estos últimos de la primera Biblia en castellano. Sin embargo, «esta primera reforma se frustró en ciernes bajo el peso de la represión inquisitorial ${ }^{41}{ }_{1}$, por tanto, no tuvo continuidad en el solar ibérico. Este hecho, como hemos indicado, provoca un impasse de ostracismo religioso que abarcará hasta la Constitución de 1869. Los motivos y causas son múltiples; desterrando

\footnotetext{
${ }^{39}$ F. Veas Arteseros, Los judios de Lorca en la Baja Edad Media, Murcia, 1992, pp. 11-20.

${ }^{40}$ Un completo estudio sobre la bibliografía existente sobre protestantismo se puede consultar en K. Van Der Grijp «Investigando la historia del protestantismo ibérico: Balance bibliográfico», Anales de historia contemporánea 17 (2001) pp. 37-52.

${ }^{41}$ J.B. Vilar, Un siglo de protestantismo en España. (Águilas- Murcia, 1893-1979). Aportación al estudio del acatolicismo español contemporáneo, Murcia, 1979, p. 3.
} 
la idea histórica de causa/efecto, es más bien un poliformismo casuístico el que, con cierto método, puede explicar el hecho religioso en Iberia.

En este caso, el protestantismo no ha supuesto para Iberia lo que sí supuso el influjo que ejercieron musulmanes -fundamentalmente norteafricanos-y judíos en territorio peninsular -sobre todo en el Sur- que, por otro lado se evidencia, no sólo en los restos edilicios y propiamente materiales que la arqueología interpreta en el presente, sino también en las propias culturas sincréticas que conforman las realidades sociales de la España contemporánea. Hay que entender cultura, no como un hecho consolidado y, por tanto acabado y totalmente definible, sino como un proceso en continua formación. Confirmar este aspecto de la morfología cultural es evidenciar que España es mestiza y sincrética por definición histórica. Por tanto, los elementos sociales, desde los estudios de la Sociología, y culturales, desde la Antropología, nos evidenciarán esa realidad histórica.

Pero a pesar de lo anterior, España ha tenido un decurso histórico que no ha permitido en muchos casos la justa permeabilidad de confesiones religiosas ajenas al catolicismo. La severidad de este hecho no desmiente el poliformismo cultural, aunque sí apunta hacia un tradicionalismo religioso que crea idiosincrasias individuales y colectivas que perduran en la actualidad: «la uniformidad religiosa -léase también ideológica- es uno de los ejes vectores de la historia española y, sin duda, figura entre los más destacados y perdurables ${ }^{42} \gg$. Y esta uniformidad del hecho religioso en la historia moderna y contemporánea reciente del territorio español, viene motivada por una tendencia ostracista que se manifiesta en tres hechos históricos que señala J.B. Vilar: la Reforma Luterana, la Revolución francesa y la «proyección del ideario marxista». Transformaciones sociales históricas que determinaron trayectorias en lo político y lo religioso de gran alcance cuyas consecuencias seculares marcan graves diferencias de España con respecto a países tales como Alemania, Francia, Bélgica, Gran Bretaña y otros estados europeos.

La configuración de la unidad religiosa, y el rechazo abierto a nuevas doctrinas viene determinado, entre otros aspectos, por el eje histórico más arriba mencionado y se observa claramente en la triple manifestación de cruzadas religiosas como apunta el profesor J.B. Vilar: la Inquisición, la guerra de la Independencia, y la guerra civil española de 1936-1939. Los acontecimientos históricos mencionados suponen un conflicto intestino del producto que genera la idea de una «España unida», cuyo proceso de gestación posiblemente comienza con los Reyes Católicos. Y decimos posiblemente porque no se puede obviar el proceso conquistador del siglo XIII: «la llegada de las nuevas creencias religiosas y el establecimiento de los centros de culto cristiano se realizó en abierta confrontación con el Islam, ya que los conquistadores eran herederos de una tradición secular de enfrentamiento ideológico y militar con la sociedad musulmana $\left.{ }^{43}{ }\right\rangle$.

\footnotetext{
42 J.B. Vilar, Intolerancia y Libertad en la España Contemporánea. Los Orígenes del Protestantismo Español Actual,Madrid, 1994, p. 23.

${ }^{43}$ M. Rodríguez Llopis, op. cit., p. 88.
} 
No obstante, el ideario centralizador -tanto ideológico/ religioso como territorialpuede situarse con los Reyes Católicos, ya que serán estos los que promuevan la verdadera centralización administrativa que sí comenzará a diseñar Carlos I y, sobre todo, su hijo Felipe II, garante de una moderna Administración territorial. Así, podemos decir que el sentido de unidad territorial y administrativa irá unido directamente al de la religión y «...desde la época de Felipe II el catolicismo llega a ser el símbolo de la unidad. La fe única representada por el catolicismo romano era el lazo que unía, o que debería unir, a los pueblos de España, tanto del continente europeo como de ultra$\operatorname{mar}^{44} \gg$. Y de esta forma, la intolerancia religiosa seguirá siendo la tónica general hasta avanzada la mitad del siglo XIX puesto que a pesar de la entrada en España del ideario liberal -con todas las connotaciones que ha tenido y tiene dicho concepto-, no siempre se mostraron visos de progreso hacia una sociedad abierta a nuevas corrientes religiosas. Así, a partir de la Constitución de 1812, que lejos de promover un ideario de pluralidad, «....adopta un criterio de unificación territorial y administrativa, ignorando con ello el sistema foral fuertemente asentado en el Antiguo Régimen, quedando toda España cortada por un mismo patrón, lo cual supuso inevitablemente la centralización. Estos hechos históricos provocarán respuestas a lo largo del siglo XIX: el carlismo y la I ${ }^{\mathrm{a}}$ República ${ }^{45}{ }$.

Con el liberalismo de la segunda mitad del siglo XIX se intentarán abrir fronteras y permeabilizar las ideas propias de una España forjada bajo una sola religión; no obstante, el clericalismo adoptará una férrea actitud ante medidas de reducción de sus parcelas de poder y bienes patrimoniales como es la desamortización llevada a cabo por Juan Álvarez Méndez (Mendizábal). Evidencia de los logros hacia la pluralidad religiosa será, entre otros, el Sexenio Revolucionario de 1868 a 1874, con el texto Constitucional de 1869. Interesa sobremanera este texto por ser el punto de inflexión en el que se sitúa la denominada II Reforma en España. De esta forma, las Cortes Constituyentes garantizaron la libertad religiosa en el Artículo 21: «La nación se obliga a mantener el culto y los ministros de la Religión Católica. El ejercicio público o privado de cualquier otro culto queda garantizado a todos los extranjeros residentes en España, sin más limitaciones que las reglas universales de la moral y el derecho. Si algunos españoles profesasen otra religión que la Católica, es aplicable a los mismos todo lo dispuesto en el párrafo anterior» (Artículo 21 de la Constitución de 1869). Todo ello favorecerá la implementación de nuevos métodos de enseñanza -aspecto decisivo en la formación y educación de la sociedad-con la creación de la Institución Libre de Enseñanza fundada en 1876 por el pedagogo Francisco Giner de los Ríos, discípulo de Sanz del Río y claro continuador del Krausismo (postura filosófica que pretendía dar visos de progreso y tolerancia al pensamiento escolástico y al conservadurismo social españoles propios de los siglos XVI al XIX). Además, será el momento en el que se forman las iglesias reformadas en España: Iglesia Española Reformada Episcopal

\footnotetext{
${ }^{44}$ M. García Ruiz, «Corrientes teológicas y sociológicas que han influido en el protestantismo español», Anales de Historia Contemporánea 17 (2001) p. 104.

${ }^{45}$ Idem, p. 104.
} 
(IERE, 1880) y la Iglesia Evangélica Española (IEE, 1886), aglutinadoras de las iglesias reformadas que irán agregándose o diluyéndose hasta la actualidad.

De este modo, llegará el momento, pasada la primera mitad del siglo XIX, en que sea posible la entrada de ideas reformistas en España y, por supuesto también en Murcia. Concretamente la pequeña población murciana de Águilas y Cartagena serán los bastiones protestantes en esta zona del sureste peninsular. Ambas poblaciones disponían de zona porteña y relaciones comerciales con ingleses lo que, sin duda, propicia la entrada de estas ideas reformistas en la Región. Uno de los primeros nombres en oírse será el del agente bíblico Graydon que llevará a cabo una intensa actividad apologética tanto en Murcia como en Cartagena que conllevará su pronta y definitiva expulsión del territorio español.

No obstante, en Cartagena, por su ya mencionada especificidad territorial portuaria, y por ende cosmopolita, «pondrá piedra» un grupo protestante español. Las relaciones comerciales, vinculadas a la minería, con Inglaterra importaron las ideas protestantes en la ciudad murciana. Destaca la figura de Charles W. Turner, «presidente de la pujante Sociedad Anglo-Hispánica, compañía minera con mayoría de accionistas británicos y participación de inversores locales, cónsul de S.M. Británica en Cartagena (...) su dilatado coto minero junto al cabo de Palos fue en más de una ocasión refugio seguro de buscados propagandistas y depósito de publicaciones protestantes entradas sin dificultad por aquel embarcadero ${ }^{46} \gg$. No obstante, a la muerte de Charles W. Turner le sucede como cónsul británico Edmund J. Turner que no haría defensa ni proselitismo del protestantismo, a diferencia de su predecesor. Así, de Cartagena «nada más sabemos sobre esta comunidad evangélica española, salvo que aparece estrechamente conectada a F. De P. Ruet y su Iglesia Española de Gibraltar, así como a las restantes colectividades reformadas de Andalucía, Levante y Cataluña, respondiendo a igual modelo confesional y organizativo de base presbiteriana ${ }^{47}$ ».

Con respecto a la localidad murciana de Águilas, comerciaba exportando barrilla y esparto a Inglaterra; por tanto, serán estas relaciones comerciales con el esparto sobre todo, las que iniciarán las inversiones británicas en esta localidad murciana. Además «...el 'boom' minero de mediados de siglo (...) provocó que los ingleses comenzaran a interesarse por el control de la riqueza minera de la zona». Y de esta forma, la hegemonía económica británica en Águilas es un hecho irrecusable cimentado sobre cuatro sólidos pilares: el puerto, el ferrocarril, las minas y el esparto ${ }^{48}$. Se forma así una colonia británica en Águilas, configurando una «perfecta sociedad colonial (...) sin grandes variantes respecto a la que se daba en Gibraltar, El Cairo o Calcuta. Superestructura inglesa, caciques locales, fuerzas disuasorias de cipayos y turbamulta de hambrientos coolíes ${ }^{49}$ ». En definitiva, una colonia inglesa elitista, mundo aparte de la población aguileña. Aspecto, este último, que queda patente en la forma de entra-

\footnotetext{
${ }^{46}$ Idem, pp. 264-265.

47 J.B. Vilar, 1994, op. cit., p. 265.

48 J.B. Vilar, 1979, op. cit. pp. 12-13.

49 Idem, p. 18.
} 
da de ideas protestantes en Águilas; no serán los ingleses los que las introduzcan sino los propios marineros que viajan a Inglaterra y que crearán, en palabras del profesor Vilar, «una iglesia sui generis, toda vez que se impusieron el compromiso de mantenerse fieles a la nueva forma de religión ${ }^{50} \gg$. Esta nueva congregación será instruida en 1893 por el célebre pastor suizo Haglund, profesor de cálculo que abandonó su carrera para dedicarse al ministerio evangélico. Además, será el mencionado pastor suizo el que realice el primer bautismo a los recién convertidos dejando constancia en un libro de registro de bautismos. Dicho documento se convierte por tanto, en una fuente imprescindible para conocer el movimiento evangélico de Águilas. De entre los catecúmenos de la población costera emergerá Pedro Román Gásquez, nombrado por el reverendo Haglund y congregantes el nuevo diácono de la congregación. Así se realizarían los cultos en su propia casa durante bastantes años.

En cuanto a la organización y ritualización de la iglesia bautista de Águilas se llevarían a cabo de forma similar a Valencia; también fueron regulados por el reverendo sueco «cultos semanales presididos por el ministro, o en su defecto por un diácono; cena del Señor en el primer domingo de cada mes; reunión mensual ordinaria. Mantenimiento del culto por los propios creyentes ${ }^{51} \gg$. Además, en cuanto a la administración de la iglesia el propio reverendo estuvo siempre por una autogestión de los propios fieles y no tanto de las ayudas externas.

Ante la pérdida de Haglund la Unión Evangélica Bautista propuso a cargo de la congregación de Águilas a León B. Armstrong «uno de los veteranos de las misiones de España ${ }^{52} \gg$. Establecido en la sociedad aguileña junto a su esposa Julie, puso vivo interés no sólo en la congregación evangélica sino también en la mejora de la infraestructura de la localidad. Y de esta manera, y con el afán del nuevo ministro, se produjo el desarrollo de la iglesia que impuso a su vez la apertura de una capilla «primera que tuvieron los evangélicos aguileños, instalada en la calle de San Sebastián, perteneciente a Francisco Serrano (...) panadero recién convertido que la cedió para este fin $^{53} \gg$.

Así, para este momento de fines del siglo XIX, la membresía de Águilas contaba con no más de veinte personas. Cómputo al que Vilar añade, citando a García Ruiz, la no inclusión de los niños en la iglesia reformada puesto que «solamente se consideraban como miembros a quienes han recibido el bautismo, el cual no se confiere generalmente a una edad menor a los diez años ${ }^{54}$ ».

Sin embargo, una nueva etapa histórica que tras el Sexenio Democrático acontece en España, la Restauración (1875-1931), será un tiempo marcado por un regreso a la rigidez de la intolerancia, así la Constitución de 1876 reduce la libertad religiosa disfrutada anteriormente a la mera tolerancia privada. Aun así, los protestantes no cejarán en su empeño por manifestar su fe públicamente y organizarán una recogida de

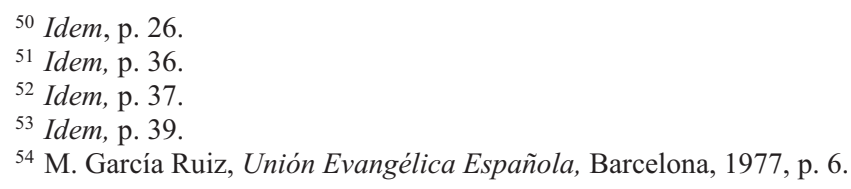


firmas que presentarán al presidente del Consejo de Ministros y miembro del Partido Liberal, José Canalejas y Méndez, el cual tuvo que acceder a que las iglesias protestantes pudieran ser identificadas mediante rótulos externos. Además, a principios del siguiente siglo la Iglesia de Roma no tuvo más remedio que abrazar las propuestas del liberalismo burgués, sobre todo ante el temor al marxismo emergente, como ha señalado Llopis: «en la región (de Murcia) esta evolución ocurrió lentamente al compás que la burguesía murciana se cohesionó como clase durante el reinado de Alfonso XII (Restauración borbónica), vencidos ya los movimientos decimonónicos del Carlismo y del republicanismo cantonalista. Iniciado el siglo XX las encíclicas papales a favor de un catolicismo social y la necesidad de encontrar fórmulas para limitar el expansionismo del movimiento obrero permitieron a la Iglesia diocesana colaborar definitivamente con la clase dirigente en la búsqueda de la estabilidad social, en una simbiosis de valores éticos y políticos casi perfecta ${ }^{55}$ ». Dicha simbiosis significó una transformación de la sociedad murciana que asimilaba gradualmente este pacto entre Iglesia y Estado en forma de sindicatos católicos, obras de socorro al obrero: Sindicato Católico Obrero de Cartagena en 1910 y el Patronato de San José Obrero en la sierra minera cartagenera en 1916; además de la instauración de la Federación Católica Agraria (1917) en el ámbito rural; Federación de Sindicatos Católicos de Obreros en el mundo urbano bajo el corolario: «Religión, Familia, Propiedad y Trabajo».

Con este panorama en Murcia y por extensión en el resto del Estado español, se produjo una represión contra los protestantes de la región; concretamente el obispo de Cartagena Tomas Bryan dará instrucciones concretas al párroco de Águilas para reprimir a aquellos que «mantuvieran trato con herejes y utilizó su influencia para que los protestantes locales no hallasen amparo ni indulgencia en la municipalidad ${ }^{56}$ ». Y todo ello en una España de la Restauración que se ha definido a sí misma como la España del caciquismo, dando con ello rienda suelta a los poderes locales que arbitraban las situaciones a su antojo.

Así, los movimientos evangélicos tuvieron que buscar estrategias y geografías regionales donde hacer proselitismo de su doctrina. Tales argumentos se constatan cuando los colportores y pastores evangélicos pregonan en lugares como Almería, que como ha señalado Vilar aludiendo a esta región de Andalucía «se hallaba en un nivel de desarrollo socioeconómico y cultural más bajo del país, y por tanto parecía terreno mejor abonado que el de Murcia para la germinación de la semilla evangélica». Realmente Andalucía ha sido la «cuna de la libertad religiosa en España» como ha señalado Vilar en su obra Intolerancia y Libertad en la España Contemporánea. Los Orígenes del Protestantismo Español Actual, 1994, y en la que realiza una argumentación de dicha afirmación que se puede sintetizar en la proximidad de Gibraltar, en la presencia de colonias extranjeras en localidades como Málaga, Sevilla y Granada, en centros mineros de Sierra Morena, pero también «se debía a la estimación de esa extensa región como campo abonado para el proselitismo por la desasistencia pastoral y la

\footnotetext{
55 M. Rodríguez Llopis, op. cit., p. 424.

56 J.B. Vilar, 1979, op. cit., p. 44.
} 
débil formación religiosa -o si se prefiere mera nominalidad católica- existente en vastos ambientes populares ${ }^{57}$ 》 y por extensión a todas los ámbitos rurales lejos del poder católico. Véase como es extensible el argumento anterior a otras zonas de España donde, como ya señalamos, la supuesta homogeneidad católica histórica es objetada cuando se analizan casos regionales locales y ambientes, sobre todo rurales, donde predominaban creencias supersticiosas y tradiciones místicas, arraigadas a la tierra y a los ciclos agrarios desde la Antigüedad ${ }^{58}$.

En las últimas décadas del siglo diecinueve, llegará a la población murciana de Águilas Robert Pollock Simpson que al igual que Haglund, abandona su carrera profesional -arquitecto- y se encamina por la senda del misionado evangélico protestante. Escocés de cuna se traslada a España siendo muy joven para perfeccionar su español en Algeciras. Después pasará a Barcelona donde trabaja en la misión regentada por Williams Brown hasta que se traslada al Sureste peninsular. Simpson se afincará en Águilas y llevará a cabo una labor evangélica de gran difusión que abarcaba también localidades limítrofes. Así, Simpson tendrá «un largo pastorado de veintisiete años (...) en el que administró el bautismo a ciento noventa conversos», con esta membresía «la improvisada capilla de la calle de San Sebastián pronto se reveló insuficiente para la celebración de los cultos ${ }^{59} \gg$. De esta forma, ante el aumento incesante de la feligresía, será erigida una nueva iglesia en la calle Jovellanos.

Debemos destacar de Robert Simpson que fue una especie de disidente del protestantismo oficial, como ha señalado Vilar, «Simpson creía firmemente en la justificación por la fe, en el poder del evangelio como instrumento de salvación, en la libertad de conciencia, en el gobierno democrático de las iglesias, en la supeditación de la jerarquía a la voluntad de los creyentes y en la separación e independencia mutua de la Iglesia y el Estado ${ }^{60}$ ». Claramente el pastor defendía una postura ideológica que difería del propio protestantismo conservador de la iglesia anglicana en Inglaterra. En este caso, además, sería imperdonable no mencionar la labor humanitaria que llevó a cabo Lina Simpson, mujer de Robert. Su labor se inicia en su propia casa donde curaba a pobres y dispensaba todos los cuidados y bienes que sus posibilidades le permitían. Con ello Lina se convirtió en algo más que en la mujer de Robert; cita el profesor Vilar una nota pie de página que pone de manifiesto el buen y extenso recuerdo que de esta buena mujer quedó en la localidad murciana: «Se me ha dicho -apunta Vilar- que circuló durante mucho tiempo una pomada fabricada por ella (Lina S.), que la gente dio en llamar «ungüento de doña Lina». Tales huellas en la reciente memoria colectiva son indicativas de la labor desempeñada al margen de la propia pastoral. Prueba de ello también lo atestigua el deseo de Lina de abrir una escuela que finalmente no fue aprobada, y una residencia de ancianos que fue una de las prime-

${ }^{57}$ Cfr. J.B. Vilar, 1979, op. cit., p.47. Idem, 1994, p. 171.

${ }^{58}$ Véase obra de referencia sobre las religiones en la historia antigua en J.M. Blázquez (ed.), Historia de las religiones de la Europa Antigua, Madrid, 1994. Concretamente el capítulo VI «La religión en el Levante Ibérico» pp. 231-260.

59 J.B. Vilar, 1979, op. cit., p. 55.

${ }^{60}$ Idem, p. 53. 
ras residencias evangélicas que funcionaron en España. Francamente, como ha puntualizado J.B. Vilar, Águilas necesitaba escuelas. Un dato nos puede clarificar aún más la situación: «para 1900 de 15.868 habitantes, 12.791 eran analfabetos y todavía en 1930 , de $15.745,9.131$ eran incapaces de dibujar su firma ${ }^{61}{ }_{\eta}$. Inefable imagen que todavía en los sesenta del siglo veinte, en el ámbito rural de gran parte de España, tristemente se reproducía, así lo supo ver de forma lúcida Delibes en su magnánima obra Los Santos Inocentes.

Cuando muere Robert Simpson en 1923 deja tras de sí una iglesia evangélica consolidada en Águilas pero también su huella se deja notar en otras localidades murcianas. Su labor fue encomiable, no sólo desde el punto de vista pastoral evangélico, sino también humanitario.

Con la dictadura de Primo de Rivera se suspenden las garantías constitucionales y se tiende hacia la uniformidad cultural y religiosa. $Y$ aunque no se persiguió a los protestantes sí «se multiplicaron en derredor suyo los obstáculos administrativos ${ }^{62}$ ». A todo ello hay que sumar un cambio copernicano en la administración pastoral: se trataba de dejar en manos de los propios españoles la dirección de las iglesias. De esta forma nadie pudo ocupar el lugar de Robert tras su ausencia, ni siquiera Lina que moriría en 1929, con lo que se tuvo que recurrir a Cartagena para los servicios de un pastor de la Iglesia Evangélica de los Hermanos. Será a finales de 1927 cuando llegue el nuevo pastor Reinaldo Barnes con el que se produjeron unas injerencias internas debido a que el citado pastor pretendió sustituir las enseñanzas bautistas por las de La Asamblea de Hermanos de Plymouth, rama disidente organizada por una asociación «de talante bíblico y democrático, articulada a base de grupos interconfesionales interesados en un estudio profundo de las Escrituras ${ }^{63} 》$.

La nueva escisión cristiana llegará a Murcia, concretamente a Cartagena, cuando en 1875 arribe el pastor John Richards. En esta ciudad portuaria se llevarán a cabo las primeras acciones de la Asamblea de Hermanos. También en la localidad de Águilas y comarca, el nuevo pastor Reinaldo Barnes promoverá el pretendido cambio en la comunidad evangélica que impulsó Simpson. Pero Barnes no podría sustituir la obra misional y humanitaria de los Simpson, aunque sí logró llevar a cabo ciertos cambios de acuerdo con el ideario de la Asamblea de Hermanos como «hacer desaparecer la Unión de Jóvenes, reducir la intervención de las mujeres en el culto a mera participación pasiva y celebró la Cena todos los domingos en vez de mensualmente $(. . .)^{64} \gg$. No obstante, en el mismo mes de julio del levantamiento militar de 1936 al llegar un buque de guerra al puerto de Águilas, Barnes y su mujer partirán de inmediato hacia Londres dejando a la feligresía aguileña de nuevo huérfana de pastor.

Pero antes de examinar el período bélico y la dictadura personalista del general Franco adviene un tiempo de cambios y promesas de futuro democrático, que serán cercenados. La Segunda República (1931-1936) proclamaba en el artículo 3 de la Cons-

\footnotetext{
${ }^{61}$ DGIGE, 1891-1982, p. 422 en J.B. Vilar, 1979, op. cit., p. 79.

62 Tuñón de Lara, 1974, pp. 151s. en J.B. Vilar, 1979, op.cit., p. 89.

63 J.B. Vilar, 1994, op. cit., pp. 97-98.

${ }^{64}$ Idem, p. 99.
} 
titución que: «El Estado español no tiene religión oficial», así también el artículo 14: «Son de exclusiva competencia del Estado español la legislación y la ejecución directa en las siguientes materias: (...) Relación entre las Iglesias y el Estado y régimen de cultos (...)» (Constitución Republicana de 1931). Así, en medio de este cambio constitucional dirigido a implementar un sistema democrático, las iglesias evangélicas se procuran un plan de actuación al socaire de la libertad religiosa la cual será cercenada brutalmente durante la dictadura del general Franco. Aunque será ya durante la guerra civil de 1936 a 1939, cuando el ambiente de anticlericalismo e irreligiosidad comience a frenar los logros alcanzados con anterioridad y pronto los evangelistas se dispersen emigrando u ocultando su fe. El local de culto de la calle Jovellanos será clausurado y «tanto los hombres como los jóvenes inspeccionaron la existencia de centros protestantes para denunciarlos y, por supuesto, para impedir su creación. La persecución se justificaba porque esas comunidades eran consideradas como cobijo de «rojos». En realidad los cristianos evangélicos españoles fueron objeto de una dura represión por su doble condición de protestantes y demócratas ${ }^{65}$ 》.

No obstante lo anterior, las confesiones protestantes en España, tras la caída de los regímenes fascistas después de la Segunda Guerra Mundial, tuvieron que ser «aceptadas» por la dictadura franquista al socaire de los nuevos aires provenientes de una Europa coaligada con Estados Unidos no sólo como héroes de la Guerra sino como autores del Plan Marshall. Así, «trece años después de Hendaya, con los acuerdos de 1953 Franco rompía por segunda vez la hipotética neutralidad tradicional española: el país quedaba integrado en el sistema defensivo occidental (frente al peligro soviético ${ }^{66}{ }_{\eta}$. La diplomacia activaba sus redes consulares y tanto británicos como estadounidenses debían de ser respetados en sus derechos de culto. Aunque la realidad fue distinta. Si bien Estados Unidos consiguió un tratado favorable en el contexto bélico de la Guerra Fría teniendo como una base más de operaciones el territorio peninsular, el protestantismo sería cegado -al margen de capitales importantes como Madrid, Barcelona, Sevilla, Valencia- sobre todo tras la firma del Concordato con el Vaticano en 1953. No obstante, y como ha señalado Vilar, se da una contradicción paradójica en relación a la tolerancia del protestantismo en España puesto que: «al espectador medio extranjero le resultaba increíble la represión obsesiva de una minoría numéricamente insignificante (protestantes), en tanto la Iglesia católica gozaba de todas las libertades en países protestantes ${ }^{67}$ ». Cabría añadir que con el pontificado de Juan XXIII y la celebración del Concilio Vaticano II se contribuye, en cierta medida, a la quiebra de la unidad del nacionalcatolicismo en la mayoría de las diócesis españolas, como ha apuntado E. Nicolás. Sin embargo, esta pérdida de unidad en el seno de la Iglesia católica y la tolerancia a cultos protestantes, tiene un proceso harto dificultoso y no exento de matices. En 1967 se modifica el fuero de los españoles y, concretamente el artículo 6 expone: «La profesión y práctica de la Religión Católica que es la del Estado

\footnotetext{
${ }^{65}$ J.B.Vilar, 2001, pp. 253-299 op.cit. en E. Nicolás Marín, La libertad encadenada. España en la dictadura franquista 1939-1975. Alianza Editorial. Madrid, 2005, p.106.

${ }^{66}$ E. Nicolás Marín, 2005, op.cit., p. 196.

${ }^{67}$ J.B. Vilar, 1979, op. cit., p. 138.
} 
español, gozará de la protección oficial. El estado asumirá la protección de la Libertad religiosa que será garantizada por una eficaz tutela jurídica que, a la vez salvaguarde la moral y el orden público». Así como «se consideran actos especialmente lesivos de los derechos reconocidos en esta ley aquello que de algún modo supongan coacción física o moral, amenaza, dádiva o promesa, captación engañosa, perturbación de la intimidad personal o familiar y cualquiera otra forma ilegítima de persuasión con el fin de ganar adeptos para una determinada creencia o confesión o desviarlos de otra» (Artículo 2 de la Ley 44/1967 reguladora del Derecho Civil a la Libertad Religiosa).

A pesar del ostracismo del Régimen franquista «en 1975 la provincia de Murcia contaba con dieciocho lugares de culto reconocido, de los cuales tres en Águilas, en la de Alicante 21, en Albacete 6 y en la de Almería 2. El máximo nacional, en la provincia de Barcelona con 110 lugares de culto. El mínimo en Toledo y Teruel, con 1 cada una ${ }^{68} \%$.

En el epílogo de la investigación de Vilar ${ }^{69}$ se apunta que a finales de la década de los setenta existían en Águilas varias confesiones protestantes: «Iglesia de las Asambleas de Hermanos», la «Misión Evangélica Bautista» y la «Iglesia Evangélica Pentecostal». Destaca también un grupo de protestantes «independientes» a cuya cabeza estaba Manuel Aullón Jorquera que, aunque se define independiente "sus convicciones son calvinistas. Su basta cultura religiosa, sus dotes de persuasión y su independencia económica le han permitido auspiciar y dirigir con cierto éxito reuniones interconfesionales de estudios bíblicos». En último lugar hace mención a dos grupos, por un lado, Católicos Independientes configurados tras el Concilio Vaticano II, «sin perjuicio de cumplir con el precepto dominical de acuerdo con la normativa romana (...) se reúnen regularmente para el estudio y exégesis de las Escrituras (...) pretenden una renovación eclesial desde la base»; en segundo lugar la «Iglesia Evangélica Española», la protestante de mayor base histórica en España aunque no logró introducirse en Águilas ${ }^{70}$.

Si la tónica general del ochocientos fue el choque frontal entre las ideologías clerical y liberal, podríamos decir que el máximo exponente de esta lucha ideológica y sociopolítica podría culminar con la Guerra Civil española de 1936 a 1939. Realmente todo lo logrado durante el Sexenio Revolucionario, la I ${ }^{a}$ República y, sobre todo la II República, serán cercenados en 1936. Durante este período, los protestantes y el resto de minorías religiosas fueron denostados y condenados a existir al margen de una legalidad ideológica que clausuró templos protestantes y obligó a sus practicantes a vivir en la clandestinidad o en el exilio, tachados de «rojos o masones» como al resto de disidentes del régimen del general Franco. Con la Constitución de 1978 se produce, lentamente, el camino hacia la normalización del hecho plural religioso que, podría decirse, ha estado latente en la realidad social española pero defenestrada hasta

${ }^{68}$ M. López Rodríguez, La España protestante. Crónica de una minoría marginada (1937-1975), Madrid, 1976, pp. 231-232.

${ }^{69}$ J.B. Vilar, 1979, op. cit.

${ }^{70}$ Idem, pp. 155-161. 
la adopción de la democracia como sistema político. Así el artículo 16 de la Constitución proclama: «La libertad religiosa pasa a ser un derecho fundamental».

En las líneas anteriores, hemos definido un largo proceso histórico analizando, sucintamente, la idiosincrasia del sentido religioso en España. Si comenzamos este apartado apuntando el sincretismo cultural de España desde la misma Antigüedad terminamos con un siglo XXI que apunta hacia una vuelta, en cierto sentido, hacia ese sincretismo, ahora mejor, pluralismo que se evidencia en una sociedad abierta y enriquecida por nuevas ideas ya provenientes de la inmigración o del salto educacional hacia un lógico encuentro entre culturas. Hemos querido exponer el tema con la intencionalidad de no rendirnos a una mera exposición historiográfica, sino como ha apuntado Van Der Grijp ${ }^{71}$ «darnos cuenta de la perspectiva en la cual hoy nos interesa el pasado», mirada prístina que, como siempre, aporta una mayor compresión de los procesos sociales del presente.

${ }^{71}$ Van Der Grijp, 2001, op.cit., p. 51. 